\title{
CD40 functional gene polymorphisms and mRNA expression in rheumatoid arthritis patients from western Mexico
}

\author{
I.V. Román-Fernández ${ }^{1}$, D.F. Ávila-Castillo ${ }^{1}$, S. Cerpa-Cruz ${ }^{2}$, \\ S. Gutiérrez-Ureña ${ }^{2}$, J. Hernández-Bello ${ }^{1}$, J.R. Padilla-Gutiérrez ${ }^{1}$, \\ Y. Valle ${ }^{1}$, M.G. Ramírez-Dueñas ${ }^{3}$, A.L. Pereira-Suárez ${ }^{3}$ and J.F. Muñoz-Valle ${ }^{1}$ \\ ${ }^{1}$ Research Institute in Biomedical Sciences, CUCS, \\ University of Guadalajara, Guadalajara, Jalisco, Mexico \\ ${ }^{2}$ Division of Rheumatology, Guadalajara Civil Hospital "Fray Antonio Alcalde", \\ Guadalajara, Jalisco, Mexico \\ ${ }^{3}$ Laboratory of Immunology, CUCS, University of Guadalajara, \\ Guadalajara, Jalisco, Mexico \\ Corresponding author: J.F. Muñoz-Valle \\ E-mail: biologiamolecular@hotmail.com
}

Genet. Mol. Res. 15 (4): gmr15048775

Received May 11, 2016

Accepted July 14, 2016

Published October 24, 2016

DOI http://dx.doi.org/10.4238/gmr15048775

Copyright $(2016$ The Authors. This is an open-access article distributed under the terms of the Creative Commons Attribution ShareAlike (CC BY-SA) 4.0 License.

\begin{abstract}
The CD40 pathway is involved in the development and pathogenesis of autoimmune diseases, including rheumatoid arthritis (RA). Two single nucleotide polymorphisms (SNPs) in the CD40 gene, rs1883832 and rs4810485, are associated with susceptibility to inflammatory and autoimmune diseases and are thought to alter CD40 expression at the mRNA and protein level. This study assessed for the first time the association of these SNPs with RA and CD40 mRNA levels in a western Mexican population. A total of 278 RA patients and 318 control subjects were included. Genotyping was performed
\end{abstract}


by polymerase chain reaction (PCR)-restriction fragment length polymorphism, and CD40 mRNA expression was determined by realtime quantitative PCR. No significant differences in genotype and allele frequencies were identified between the RA patients and controls. When stratified by genotype, these SNPs were not found to be associated with the presence of autoantibodies or the clinical activity of the disease. CD40 mRNA levels were elevated 1.5-fold in RA patients compared to control subjects; however, no clear tendencies were observed following stratification by genotype. These results suggest that the CD40 SNPs rs1883832 and rs4810485 are not RA susceptibility markers in the western Mexican population. Further studies are needed to clarify their roles in $C D 40$ mRNA expression.

Key words: CD40; SNP; Rheumatoid arthritis; Autoimmunity; qPCR

\section{INTRODUCTION}

Rheumatoid arthritis (RA) is a chronic inflammatory autoimmune disease that affects diarthrodial joints. RA affects $\sim 1 \%$ of the world's population and is characterized by synovial hyperplasia, infiltration of large numbers of inflammatory cells into the joints, production of autoantibodies, systemic inflammation, and cardiovascular complications (McInnes and Schett, 2011; Arend and Firestein, 2012).

The etiology of RA is unknown, but it is hypothesized that certain environmental factors trigger an autoimmune process in genetically susceptible individuals. Human leukocyte antigen (HLA) alleles, particularly those encoding the shared epitope, confer approximately one third of the genetic risk associated with this disease (Perricone et al., 2011). Other nonHLA risk loci for RA, including the CD40 gene, have been identified based on genome-wide association studies and meta-analysis (Wellcome Trust Case Control Consortium, 2007; Raychaudhuri et al., 2008; Perricone et al., 2011; Suzuki et al., 2011). Interestingly, CD40 has been implicated in other autoimmune diseases, such as multiple sclerosis [MS; Australia and New Zealand Multiple Sclerosis Genetics Consortium (ANZgene), 2009], Grave's disease (GD; Li et al., 2012), systemic lupus erythematosus (SLE; Vazgiourakis et al., 2011), and Crohn's disease (Blanco-Kelly et al., 2010).

$\mathrm{CD} 40$, a $48-\mathrm{kDa}$ transmembrane protein, is a member of the tumor necrosis factor receptor superfamily that is expressed in a constitutive and/or inducible fashion on antigenpresenting cells (APCs), monocytes, and T cells, as well as non-immune cells including fibroblasts, endothelial, smooth muscle, and epithelial cells. By binding with its ligand CD40L (CD154), which is mainly expressed by activated CD4+ T cells, CD40 signaling mediates several processes involved in the regulation of cellular and humoral adaptive immune responses. These include $\mathrm{T}$ cell priming, APC activation, germinal center formation and immunoglobulin (Ig) class switching, in addition to inducing the expression of a plethora of proteins, such as proinflammatory cytokines, chemokines, and costimulatory and adhesion molecules (Elgueta et al., 2009).

Multiple studies have found that CD40 plays a key role in the pathogenesis of several chronic inflammatory and autoimmune diseases (Peters et al., 2009). Its involvement in the pathogenesis of RA has been under scrutiny for several years. Interestingly, several regulatory

Genetics and Molecular Research 15 (4): gmr15048775 
pathways that are altered in RA may involve CD40 (Yi et al., 2013). It has been reported that CD40 is overexpressed in CD4+ and CD8+ T cells and monocytes from the synovial fluid of RA patients (Liu et al., 2001). Furthermore, it is now known that CD40 signals are required for the production of IgM anti-cyclic citrullinated peptide antibodies by B cells in RA patients and healthy subjects (Reparon-Schuijt et al., 2001). CD40 also induces expression of VEGF and RANKL in synovial fibroblasts, molecules that have an important influence on the progression and severity of RA (Cho et al., 2000; Lee et al., 2006).

Two functional single nucleotide polymorphisms (SNPs) in the CD40 gene, rs1883832 and rs4810485, which are in strong linkage disequilibrium $\left(r^{2}=0.95\right)$, have been previously associated with RA in European populations (Raychaudhuri et al., 2008; Orozco et al., 2010; García-Bermúdez et al., 2012; Lee et al., 2015). The former is located at position -1 in the Kozak sequence, and it has been proposed that the major allele of this SNP enhances the efficiency of CD40 mRNA translation, resulting in up to $32 \%$ more CD40 protein (Jacobson et al., 2005). Moreover, some studies have reported that the minor $\mathrm{T}$ allele is associated to decreased CD40 mRNA and increased soluble CD40 levels (Chen et al., 2015; Field et al., 2015; Wagner et al., 2015). Although the T allele of rs 1883832 has been associated with increased susceptibility to MS and SLE among Russian and Chinese individuals, respectively (Sokolova et al., 2013; Chen et al., 2015), it has also been reported to have a protective effect for RA in the Spanish population (García-Bermúdez et al., 2012). Meanwhile, rs4810485, located in the second intron of CD40, is thought to affect CD40 mRNA and protein expression in B cells and monocytes (Vazgiourakis et al., 2011). Interestingly, the minor allele of this SNP is associated with breast cancer risk in the Chinese population (Shuang et al., 2011), whereas among Europeans, it has been suggested to be protective for the development of RA (Orozco et al., 2010; Lee et al., 2015).

To date, these genetic variants and their relationship with RA have not been studied in the Mexican population. Given the associations between these SNPs and this disease in other populations, their possible influence on CD40 mRNA and protein expression, and the important role that CD40 plays in autoimmune pathogenesis, we aimed to investigate the association of rs 1883832 and rs4810485 with rheumatoid arthritis and CD40 mRNA levels in the western Mexican population.

\section{MATERIAL AND METHODS}

\section{Subjects}

A total of 278 patients with RA classified according to the 2010 American College of Rheumatology and the European League Against Rheumatism criteria (Aletaha et al., 2010) were recruited from Hospital Civil de Guadalajara "Fray Antonio Alcalde", Guadalajara, Mexico. Patients with other rheumatic, infectious, or inflammatory diseases were excluded. In addition, 318 unrelated control subjects with no personal or familial history of autoimmune disorders were included. For both groups, we only considered mestizo individuals from western Mexico of families that for at least three generations, including the participant's own, have been born in this country.

The ethical principles of the Declaration of Helsinki were followed. Participation of all subjects was voluntary and each signed a written informed consent form. This study was approved by the Ethics Committee of Hospital Civil de Guadalajara "Fray Antonio Alcalde" and Centro Universitario de Ciencias de la Salud, Universidad de Guadalajara.

Genetics and Molecular Research 15 (4): gmr15048775 


\section{Genotyping of rs1883832 and rs4810485 CD40 SNPs}

Genomic DNA was extracted from peripheral blood leukocytes using previously described methods (Miller et al., 1988). Genotyping of rs1883832 and rs4810485 was performed by polymerase chain reaction (PCR)-restriction fragment length polymorphism. Target regions of $C D 40$ containing the polymorphisms of interest were amplified by PCR using the following primers, modified from Chen et al. (2012): rs1883832, forward 5'-CCC CGA TAG GTG GAC CGC GAT TGG T-3' and reverse 5'-CCC GCC CTC TGA ACC CCC TAC CAG T-3'; rs4810485, forward 5'-TAT TTT TGT AGT TCC TCA TTC TGG A-3' and reverse 5'-GCC CCC CTT TAC CTC TTT CCA-3'. For rs1883832, PCR was carried out in a total volume of $15 \mu \mathrm{L}$, containing $100 \mathrm{ng}$ genomic DNA, 1 X PCR buffer, $1.5 \mathrm{mM} \mathrm{MgCl}$, $0.1 \mathrm{mM}$ deoxynucleotides (dNTPs), $0.09 \mu \mathrm{M}$ of each primer, and $0.4 \mathrm{U}$ Taq DNA polymerase (Invitrogen, Carlsbad, CA, USA). Cycling conditions were as follows: 5 min initial denaturation at $95^{\circ} \mathrm{C}, 30$ cycles of $95^{\circ} \mathrm{C}$ for $30 \mathrm{~s}, 60^{\circ} \mathrm{C}$ for $30 \mathrm{~s}$, and $72^{\circ} \mathrm{C}$ for $45 \mathrm{~s}$, with a final extension for $10 \mathrm{~min}$ at $72^{\circ} \mathrm{C}$. The major allele sequence yielded fragments of 373 and $132 \mathrm{bp}$ when the 505-bp PCR product was digested with $5 \mathrm{U}$ NcoI enzyme (New England Biolabs, Ipswich, MA, USA) for $1 \mathrm{~h}$ at $37^{\circ} \mathrm{C}$. PCR for rs 4810485 was performed in a total volume of $15 \mu \mathrm{L}$, and comprised $300 \mathrm{ng}$ genomic DNA, 1X PCR buffer, $2.0 \mathrm{mM} \mathrm{MgCl}_{2}, 0.1 \mathrm{mM}$ dNTPs, $0.09 \mu \mathrm{M}$ of each primer, and 0.4 U Taq DNA polymerase (Invitrogen). The following cycling conditions were used: initial denaturation for $5 \mathrm{~min}$ at $94^{\circ} \mathrm{C}$, followed by 35 cycles of $30 \mathrm{~s}$ at $94^{\circ} \mathrm{C}, 30 \mathrm{~s}$ at $62^{\circ} \mathrm{C}$, and $30 \mathrm{~s}$ at $72^{\circ} \mathrm{C}$, before a final extension for $5 \mathrm{~min}$ at $72^{\circ} \mathrm{C}$. Restriction with $5 \mathrm{U} \mathrm{MspI}$ endonuclease (New England Biolabs) was carried out for $2 \mathrm{~h}$ at $37^{\circ} \mathrm{C}$. The 283-bp major allele PCR product was cleaved into fragments of 180 and $103 \mathrm{bp}$.

\section{Quantitative CD40 mRNA expression analysis}

Relative quantification of $C D 40$ mRNA was performed by real-time quantitative PCR (qPCR). For this purpose, total RNA was extracted from the peripheral blood leukocytes of RA patients and control subjects carrying the CC/GG, CT/GT, and TT/TT rs1883832/rs4810485 genotypes. This was achieved using the modified Chomczynski and Sacchi method (Chomczynski and Sacchi, 1987). Total RNA (1 mg) was then reverse transcribed using oligo-dT and Moloney murine leukemia virus reverse transcriptase (Promega Corp., Madison, WI, USA) following the manufacturer protocol, and the resulting complementary DNA (cDNA) was stored at $-80^{\circ} \mathrm{C}$ until use. $C D 40 \mathrm{mRNA}$ was measured using hydrolysis probes (Roche Diagnostics, Basel, Switzerland). Primers and probes were obtained from Roche Diagnostics (probe No. 34, cat. No. 04687671001) using their Universal ProbeLibrary System Assay Design web tool. The glyceraldehyde 3-phosphate dehydrogenase (GAPDH) gene was used as reference gene (Roche Diagnostics). qPCRs were performed with 100 ng cDNA in a LightCycler Nano instrument (Roche Diagnostics); all samples were run in duplicate, or in triplicate when necessary. A validation experiment using serial dilutions of cDNA was conducted beforehand in order to verify amplification efficiencies for both genes. Data were analyzed by the $2^{-\Delta \mathrm{Cq}}$ and $2^{-\Delta \mathrm{ACq}}$ comparative methods, as described by Livak and Schmittgen (2001) and Schmittgen and Livak (2008), respectively.

\section{Statistical analysis}

Statistical analysis was carried out using Stata version 12.0 (StataCorp, College

Genetics and Molecular Research 15 (4): gmr15048775 
Station, TX, USA) and GraphPad Prism version 5.0 (GraphPad Software, San Diego, CA, USA). The chi-square test was used for comparison of genotype and allele frequencies and for Hardy-Weinberg equilibrium (HWE) calculations. Odds ratios and 95\% confidence intervals were calculated to determine the probability that genotypes and alleles were associated with RA. ANOVA test was employed for parametric data, and the Mann-Whitney U and Kruskal-Wallis tests were used for nonparametric data. $\mathrm{P}$ values $<0.05$ were considered statistically significant.

\section{RESULTS}

\section{Clinical features of RA patients}

Table 1 summarizes the demographic and clinical features of the RA patients. The average age in this group was $47.23 \pm 13.12$ years, and $91 \%$ of patients were women. Median disease duration was 4 years, and on average, patients were moderately disabled (1.11) according to the Spanish Health Assessment Questionnaire-Disability Index (HAQ-DI), and exhibited moderate disease activity (4.28), as measured by Disease Activity Score-28 (DAS28). Regarding the presence of autoantibodies, rheumatoid factor (RF) was detected in $91 \%$ of patients, whereas $77 \%$ tested positive for anti-citrullinated protein antibodies. In addition, 64 and $70 \%$ had high levels of these antibodies, respectively.

\begin{tabular}{|c|c|}
\hline Variable & $\mathrm{N}=278$ \\
\hline \multicolumn{2}{|l|}{ Demographics } \\
\hline Age (years) ${ }^{\mathrm{a}}$ & $47.23 \pm 13.12$ \\
\hline \multicolumn{2}{|l|}{ Gender $^{\mathrm{b}}$} \\
\hline Female & $91(252)$ \\
\hline Male & $9(26)$ \\
\hline \multicolumn{2}{|l|}{ Disease status } \\
\hline Disease duration (years) $^{\mathrm{c}}$ & $4(0.5-22)$ \\
\hline \multicolumn{2}{|l|}{ Clinical assessment } \\
\hline Spanish HAQ-DI score ${ }^{\mathrm{c}}$ & $1.11(0.0-2.56)$ \\
\hline DAS-28 score $\mathrm{a}^{\mathrm{a}}$ & $4.28 \pm 1.27$ \\
\hline \multicolumn{2}{|l|}{ DAS- $28^{\mathrm{b}}$} \\
\hline Remission $(<2.6)$ & $7(19)$ \\
\hline Low activity $(\geq 2.6,<3.2)$ & $17(45)$ \\
\hline Moderate activity $(\geq 3.2,<5.1)$ & $49(132)$ \\
\hline High activity $(\geq 5.1)$ & $27(74)$ \\
\hline Rheumatoid factor $(\mathrm{IU} / \mathrm{mL})^{\mathrm{c}}$ & $92.64(11.4-300)$ \\
\hline \multicolumn{2}{|l|}{ Rheumatoid factor ${ }^{\mathrm{b}}$} \\
\hline Negative $(<20 \mathrm{IU} / \mathrm{mL})$ & $9(19)$ \\
\hline Positive ( $\geq 20 \mathrm{IU} / \mathrm{mL}$ ) & $27(58)$ \\
\hline High positive $(\geq 60 \mathrm{IU} / \mathrm{mL})$ & $64(135)$ \\
\hline C-reactive protein $(\mathrm{mg} / \mathrm{dL})^{\mathrm{c}}$ & $17.4(1.7-204.9)$ \\
\hline $\mathrm{ACPA}(\mathrm{U} / \mathrm{mL})^{\mathrm{c}}$ & $55.4(1.4-353.4)$ \\
\hline \multicolumn{2}{|l|}{$\mathrm{ACPA}^{\mathrm{b}}$} \\
\hline Negative $(<5 \mathrm{U} / \mathrm{mL})$ & $23(43)$ \\
\hline Positive $(\geq 5 \mathrm{U} / \mathrm{mL})$ & $7(14)$ \\
\hline High positive $(\geq 15 \mathrm{U} / \mathrm{mL})$ & $70(132)$ \\
\hline \multicolumn{2}{|l|}{ Treatment ${ }^{b}$} \\
\hline NSAIDs & $67(182)$ \\
\hline Steroids & $27(71)$ \\
\hline Methotrexate & $81(217)$ \\
\hline Sulfasalazine & $49(132)$ \\
\hline Chloroquine & $35(93)$ \\
\hline
\end{tabular}

Genetics and Molecular Research 15 (4): gmr15048775 


\section{Genotype and allele frequencies of rs1883832 and rs4810485 CD40 SNPs}

The genotype distributions of both SNPs conformed to HWE in the control group ( $\mathrm{P}=0.86$ and 0.48 for $\mathrm{rs} 1883832$ and $\mathrm{rs} 4810485$, respectively). rs 1883832 and rs 4810485 distribution of the genotype and allele frequencies (Table 2) did not significantly differ between RA patients and control subjects. Interestingly, the minor allele frequencies of both $C D 40$ genetic variants identified in this study were lower than those reported previously for European and Asian populations (García-Bermúdez et al., 2012; Liu et al., 2012; Lee et al., 2015). In addition, no association with RA was observed under any genetic model.

Table 2. Genotype and allele frequencies of the rs 1883832 and rs $4810485 C D 40$ gene polymorphisms in rheumatoid arthritis patients (RA) and control subjects (CS).

\begin{tabular}{|c|c|c|c|c|c|}
\hline SNP & RA \% $(\mathrm{N}=278)$ & $\mathrm{CS} \%(\mathrm{~N}=318)$ & $P_{\text {value }}{ }^{a}$ & OR $(95 \% \mathrm{CI})$ & P value $\mathrm{a}^{\mathrm{a}}$ \\
\hline \multicolumn{6}{|l|}{ rs 1883832} \\
\hline \multicolumn{6}{|l|}{ Genotype } \\
\hline $\mathrm{C} / \mathrm{C}^{\mathrm{b}}$ & $66.2(184)$ & $64.4(205)$ & \multirow[t]{3}{*}{0.91} & 1 & - \\
\hline $\mathrm{C} / \mathrm{T}$ & $30.6(85)$ & $32.1(102)$ & & $0.93(0.64-1.34)$ & 0.68 \\
\hline $\mathrm{T} / \mathrm{T}$ & $3.2(9)$ & $3.5(11)$ & & $0.91(0.33-2.48)$ & 0.84 \\
\hline \multicolumn{6}{|l|}{ Allele } \\
\hline $\mathrm{C}^{\mathrm{b}}$ & $81.5(453)$ & $80.5(512)$ & \multirow[t]{2}{*}{0.67} & 1 & - \\
\hline $\mathrm{T}$ & $18.5(103)$ & $19.5(124)$ & & $0.94(0.69-1.27)$ & 0.67 \\
\hline \multicolumn{6}{|c|}{ Genetic model } \\
\hline \multicolumn{6}{|l|}{ Dominant } \\
\hline $\mathrm{C} / \mathrm{C}^{\mathrm{b}}$ & $66.2(184)$ & $64.5(205)$ & \multirow[t]{2}{*}{0.66} & 1 & - \\
\hline $\mathrm{C} / \mathrm{T}+\mathrm{T} / \mathrm{T}$ & $33.8(94)$ & $35.5(113)$ & & $0.93(0.65-1.32)$ & 0.66 \\
\hline \multicolumn{6}{|l|}{ rs 4810485} \\
\hline \multicolumn{6}{|l|}{ Genotype } \\
\hline $\mathrm{G} / \mathrm{G}^{\mathrm{b}}$ & $65.8(183)$ & $63.6(202)$ & \multirow[t]{3}{*}{0.75} & 1 & - \\
\hline $\mathrm{G} / \mathrm{T}$ & $30.6(85)$ & $33.3(106)$ & & $0.89(0.61-1.27)$ & 0.49 \\
\hline $\mathrm{T} / \mathrm{T}$ & $3.6(10)$ & $3.1(10)$ & & $1.10(0.40-3.03)$ & 0.83 \\
\hline \multicolumn{6}{|l|}{ Allele } \\
\hline $\mathrm{G}^{\mathrm{b}}$ & $81.1(451)$ & $80.2(510)$ & \multirow[t]{2}{*}{0.69} & 1 & - \\
\hline $\mathrm{T}$ & $18.9(105)$ & $19.8(126)$ & & $0.94(0.70-1.27)$ & 0.69 \\
\hline \multicolumn{6}{|c|}{ Genetic model } \\
\hline \multicolumn{6}{|l|}{ Dominant } \\
\hline $\mathrm{G} / \mathrm{G}^{\mathrm{b}}$ & $65.8(183)$ & $63.5(202)$ & \multirow[t]{2}{*}{0.56} & 1 & - \\
\hline $\mathrm{G} / \mathrm{T}+\mathrm{T} / \mathrm{T}$ & $34.2(95)$ & $36.5(116)$ & & $0.90(0.64-1.28)$ & 0.56 \\
\hline
\end{tabular}

${ }^{\mathrm{a}} \mathrm{Chi}$-square test, ${ }^{\mathrm{b}}$ reference. $\mathrm{OR}=$ odds ratio, $\mathrm{CI}=$ confidence interval.

\section{Clinical features of RA patients in relation to $C D 40$ rs1883832 and rs4810485 genotypes}

In order to establish whether the CD40 SNPs under investigation are associated with RA clinical activity (based on the Spanish HAQ-DI index and DAS-28) or clinical features (disease duration, and levels of acute phase reactants and autoantibodies), we evaluated these after stratifying the data by rs 1883832 and rs 4810485 genotypes (Tables 3 and 4, respectively). We did not detect any relationship between these clinical variables and $C D 40$ polymorphisms.

\section{Comparison of CD40 mRNA expression between RA patients and control subjects according to rs1883832/rs4810485 genotype}

Considering the various reports concerning the influence of rs 1883832 and rs 4810485 on CD40 mRNA expression, we evaluated CD40 transcript levels by real-time qPCR in 
Table 3. Clinical features of rheumatoid arthritis patients stratified according to rs1883832 CD40 genotype.

\begin{tabular}{l|c|c|c|c}
\hline Variable & CC & CT & TT & P value \\
\hline Disease status & & & & \\
\hline Disease duration (years) $)^{\mathrm{a}}$ & $4(0.4-23)$ & $3.5(0.5-15)$ & $5(0.5-34)$ & $0.61^{\mathrm{c}}$ \\
\hline Clinical assessment $^{\mathrm{c}}$ & & & & \\
\hline ESR $^{\mathrm{a}}$ & $35(12-55)$ & $35.5(10-61)$ & $30(7-80)$ & $0.60^{\mathrm{c}}$ \\
\hline DAS-28 score $^{\mathrm{b}}$ & $4.2 \pm 1.3$ & $4.4 \pm 1.2$ & $4.3 \pm 1.9$ & $0.18^{\mathrm{d}}$ \\
\hline Spanish HAQ-DI score & $0.8(0-2.6)$ & $1.2(0.2-2.9)$ & $1.4(0.3-2.4)$ & $0.33^{\mathrm{c}}$ \\
\hline${\text { Rheumatoid factor }(\mathrm{IU} / \mathrm{mL})^{\mathrm{a}}}^{\mathrm{a}}$ & $84.7(12.7-300)$ & $125(9.7-650)$ & $156.3(15.8-459)$ & $0.18^{\mathrm{c}}$ \\
\hline${\text { C-reactive protein }(\mathrm{mg} / \mathrm{dL})^{\mathrm{a}}}^{\text {Anti-CCP antibody }(\mathrm{U} / \mathrm{mL})^{\mathrm{a}}}$ & $17.9(1.7-185)$ & $16.7(1.9-238.6)$ & $13.9(1.2-353.9)$ & $0.68^{\mathrm{c}}$ \\
\hline
\end{tabular}

${ }^{a}$ Data are reported as medians (and 5th-95th percentiles), ${ }^{\text {bdata }}$ are reported as means \pm standard deviations, ${ }^{\mathrm{c}}$ Kruskal-Wallis test, ${ }^{\mathrm{d}}$ ANOVA test. ESR = erythrocyte sedimentation rate, DAS-28 = Disease Activity Score-28, HAQ-DI = Health Assessment Questionnaire-Disability Index, CCP = cyclic citrullinated peptide.

Table 4. Clinical features of rheumatoid arthritis patients stratified according to rs4810485 CD40 genotype.

\begin{tabular}{l|c|c|c|c}
\hline Variable & GG & GT & TT & P value \\
\hline Disease status & & & & \\
\hline Disease duration (years) & $4(0.4-23)$ & $4(0.5-18)$ & $4(0.5-34)$ & $0.90^{\mathrm{c}}$ \\
\hline Clinical assessment $^{\mathrm{a}}$ & & & & \\
\hline ESR $^{\mathrm{a}}$ & $35(12-55)$ & $35(10-61)$ & $32.5(7-80)$ & $0.70^{\mathrm{c}}$ \\
\hline DAS-28 score $^{\mathrm{b}}$ & $4.2 \pm 1.3$ & $4.4 \pm 1.2$ & $4.3 \pm 1.8$ & $0.25^{\mathrm{d}}$ \\
\hline Spanish HAQ-DI score & $0.8(0-2.6)$ & $1.2(0.2-2.9)$ & $1.4(0.3-2.4)$ & $0.33^{\mathrm{c}}$ \\
\hline${\text { Rheumatoid factor }(\mathrm{IU} / \mathrm{mL})^{\mathrm{a}}}^{\mathrm{a}}$ & $84.1(12-300)$ & $125(9.7-650)$ & $142.9(15.8-459)$ & $0.16^{\mathrm{c}}$ \\
\hline C-reactive protein $(\mathrm{mg} / \mathrm{dL})^{\mathrm{a}}$ & $17.8(1.7-185)$ & $16.7(1.9-238.6)$ & $18(1.2-353.9)$ & $0.92^{\mathrm{c}}$ \\
\hline${\text { Anti-CCP antibody }(\mathrm{U} / \mathrm{mL})^{\mathrm{a}}}^{\mathrm{a}}$ & $56.6(1.4-340.6)$ & $51.5(1.4-353.4)$ & $19.8(1.1-510.7)$ & $0.45^{\mathrm{c}}$ \\
\hline
\end{tabular}

${ }^{a}$ Data are reported as medians (and 5th-95th percentiles), bdata are reported as means \pm standard deviations, ${ }^{\mathrm{c}}$ Kruskal-Wallis test, ${ }^{\mathrm{d}}$ ANOVA test. ESR $=$ erythrocyte sedimentation rate, DAS-28 $=$ Disease Activity Score-28, HAQ-DI = Health Assessment Questionnaire-Disability Index, CCP = cyclic citrullinated peptide.

total peripheral blood leukocytes from RA patients and control subjects carrying different rs 1883832/rs4810485 genotypes. First, using the $2^{-\Delta C q}$ method, we observed that RA patients had higher levels of CD40 mRNA compared to controls, although this difference was not significant (Figure 1A). Stratifying the results by rs1883832/rs4810485 genotype, control subjects with $\mathrm{CT} / \mathrm{GT}$ and TT/TT genotypes demonstrated a slight tendency for decreased CD40 mRNA expression compared to $\mathrm{CC} / \mathrm{GG}$ carriers; however, this difference was not significant. In contrast, in the RA group, increased CD40 mRNA levels were observed in carriers of $\mathrm{CT} / \mathrm{GT}$ and TT/TT genotypes compared with $\mathrm{CC} / \mathrm{GG}$ patients, but this observation was also statistically non significant (Figure 1B).

After analyzing the data by the $2^{-\Delta \Delta \mathrm{Ca}}$ method, we found that RA patients expressed 1.5-fold more CD40 mRNA compared to control subjects (Figure 1C). Stratification by rs 1883832/rs4810485 genotype revealed that control subjects with the CT/GT genotype had 1.3-fold higher $C D 40$ transcript levels compared with CC/GG carriers. Unlike heterozygous individuals, TT/TT carriers showed diminished $C D 40$ mRNA expression (1.3-fold) compared to those carrying the $\mathrm{CC} / \mathrm{GG}$ genotype. A different pattern was observed in the RA group, in that $\mathrm{CT} / \mathrm{GT}$ and TT/TT carriers had higher $C D 40 \mathrm{mRNA}$ levels than patients of the CC/GG genotype (1.6- and 1.3-fold, respectively; Figure 1D).

Genetics and Molecular Research 15 (4): gmr15048775 
A

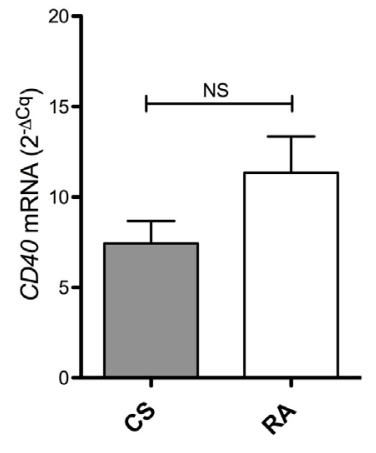

C

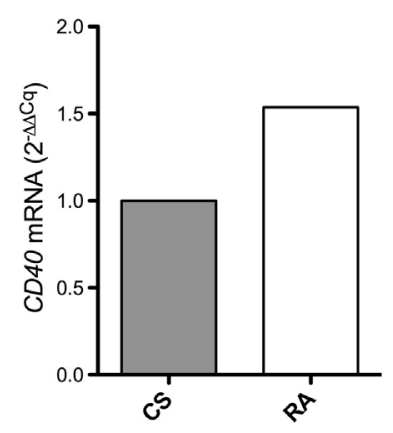

B

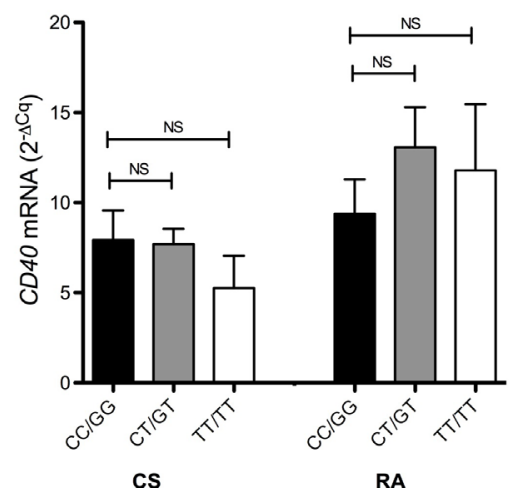

D

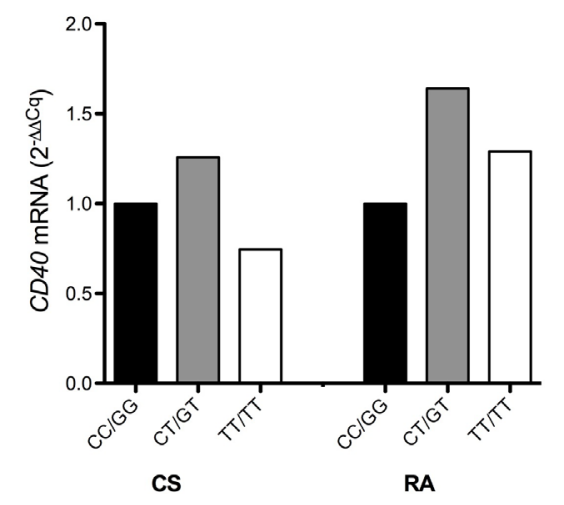

Figure 1. Comparison of $C D 40$ mRNA expression in rheumatoid arthritis patients (RA) and control subjects (CS) stratified by rs1883832/rs4810485 genotype. Data were analyzed by the $2^{-\Delta \mathrm{Cq}}(\mathbf{A}, \mathbf{B})$ and $2^{-\Delta \Delta \mathrm{Cq}}(\mathbf{C}, \mathbf{D})$ comparative methods. Differences between groups were determined by the Mann-Whitney U-test using $2^{-\Delta C q}$ analysis. NS $=$ not significant.

\section{DISCUSSION}

CD40 plays an important role in the regulation of cellular and humoral adaptive immune responses, and has therefore been associated with the pathogenesis of several autoimmune and inflammatory diseases, including that of RA (Peters et al., 2009). The CD40 SNPs rs 1883832 and rs4810485 have been identified as susceptibility markers for this and other autoimmune diseases, such as GD (Tomer et al., 2002; Kim et al., 2003; Li et al., 2012), MS (Blanco-Kelly et al., 2010; Sokolova et al., 2013), and SLE (Vazgiourakis et al., 2011; Chen et al., 2015; Lee et al., 2015). In addition, several studies suggest that these polymorphisms affect CD40 expression at the mRNA and protein level (Jacobson et al., 2005; Vazgiourakis et al., 2011; Field et al., 2015; Wagner et al., 2015). In this investigation, we assessed for the first time the association between these two functional $C D 40$ variants and susceptibility to RA in the Mexican population. 
We observed no significant differences in rs1883832 and rs4810485 genotype and allele frequencies between RA patients and control subjects. Although these polymorphisms have been identified as genetic risk factors in different European populations, this was not reflected in our findings, this could be due to differences in ancestry. The genetic background of the Mexican mestizo population comprises a combination of Amerindian, European, and African ancestries, with estimated respective contributions of $21-25,60-64$, and $15 \%$ (Martínez-Cortés et al., 2012). However, owing to the rather heterogeneous genetic background of the Mexican population, and the fact that the present study only examined individuals from western Mexico, our results do not rule out the possibility that these and other CD40 genetic variants are associated with RA in groups from other regions of this country.

Given the function of CD40 in promoting Ig class switching, the activation and proliferation of $\mathrm{B}$ cells, and stimulating the production of several proinflammatory cytokines, it is logical to suppose that the functional polymorphisms studied here may be associated with autoantibody production and RA clinical activity. This relationship has already been reported by Orozco et al. (2010), who found a strong link between rs 4810485 and the presence of RF and anti-CCP antibodies in the UK population. When we analyzed the clinical features of RA patients after stratification according to rs 1883832 and rs4810485 genotypes, no associations were observed between these SNPs and clinical disease activity or autoantibody presence in our study population. Over the past few years, it has become evident that in the development of complex inflammatory diseases, genetic risk factors are not homogeneous among different populations; such is the case for RA. Thus, the identification of a genetic factor as a marker of susceptibility in one population may not hold in others.

In our analysis of $C D 40$ expression, we found no clear association between mRNA levels and rs1883832/rs4810485 genotype. Given that genetic risk factors for RA vary between populations, we must consider that other, potentially more prevalent, $C D 40$ genetic variants may affect mRNA levels among Mexicans. Moreover, we should not lose sight of the fact that $C D 40$ expression is regulated by several mechanisms that may impact the number of transcripts produced and can be extremely variable in diseases involving inflammatory processes, such as RA. It is worthy of mention that the expression analysis was performed using total peripheral blood leukocytes; separating and analyzing only those cell subpopulations that constitutively express CD40 may be more informative. In addition, the sample size used in this study was relatively small and the clinical activity of the disease was not considered for the inclusion of the subjects in the expression assay. These factors may have limited our analysis. An association between the minor $\mathrm{T}$ allele of rs4810485 and down-regulation of CD40 mRNA has been previously described (Vazgiourakis et al., 2011). However, conflicting results have been obtained regarding the rs1883832 SNP. Some reports have identified a relationship between this genetic variant and CD40 transcript levels. For instance, Field et al. (2015) found the minor T allele to be associated with reduced CD40 expression in APCs, related to an increased proportion of the short mRNA isoform encoding the secreted form of CD40. This is consistent with the work of Chen et al. (2015), who observed elevated levels of soluble CD40 in SLE patients carrying the T allele. On the other hand, Jacobson et al. (2005) showed that the rs1883832 SNP does not affect transcription, but can influence translation efficiency. Considering this, we suggest that further studies focusing on this matter need to be carried out. In conclusion, our findings indicate that the functional CD40 SNPs rs 1883832 and rs4810485 are not genetic markers of RA susceptibility, and do not affect CD40 mRNA levels in the western Mexican population. Further research is needed to clarify the influence of

Genetics and Molecular Research 15 (4): gmr15048775 
these and other CD40 genetic variants on RA risk, and their role in CD40 mRNA and protein expression, to better understand the involvement of the CD40 pathway in the pathogenesis of this disease among Mexicans.

\section{Conflicts of interest}

The authors declare no conflict of interest.

\section{ACKNOWLEDGMENTS}

Research supported by funding from the National Council of Science and Technology (CONACYT, grant \#180663), CONACYT-México-Universidad de Guadalajara, awarded to J.F. Muñoz-Valle. The funding source had no involvement in any phase of the study.

\section{REFERENCES}

Aletaha D, Neogi T, Silman AJ, Funovits J, et al. (2010). 2010 Rheumatoid arthritis classification criteria: an American College of Rheumatology/European League Against Rheumatism collaborative initiative. Arthritis Rheum. 62: 25692581. http://dx.doi.org/10.1002/art.27584

Arend WP and Firestein GS (2012). Pre-rheumatoid arthritis: predisposition and transition to clinical synovitis. Nat. Rev. Rheumatol. 8: 573-586. http://dx.doi.org/10.1038/nrrheum.2012.134

Australia and New Zealand Multiple Sclerosis Genetics Consortium (ANZgene) (2009). Genome-wide association study identifies new multiple sclerosis susceptibility loci on chromosomes 12 and 20. Nat. Genet. 41: 824-828. http:// dx.doi.org/10.1038/ng.396

Blanco-Kelly F, Matesanz F, Alcina A, Teruel M, et al. (2010). CD40: novel association with Crohn's disease and replication in multiple sclerosis susceptibility. PLoS One 5: e11520. http://dx.doi.org/10.1371/journal.pone.0011520

Chen F, Hou S, Jiang Z, Chen Y, et al. (2012). CD40 gene polymorphisms confer risk of Behcet's disease but not of Vogt-Koyanagi-Harada syndrome in a Han Chinese population. Rheumatology 51: 47-51. http://dx.doi.org/10.1093/ rheumatology/ker345

Chen JM, Guo J, Wei CD, Wang CF, et al. (2015). The association of CD40 polymorphisms with CD40 serum levels and risk of systemic lupus erythematosus. BMC Genet. 16: 121. http://dx.doi.org/10.1186/s12863-015-0279-8

Cho CS, Cho ML, Min SY, Kim WU, et al. (2000). CD40 engagement on synovial fibroblast up-regulates production of vascular endothelial growth factor. J. Immunol. 164: 5055-5061. http://dx.doi.org/10.4049/jimmunol.164.10.5055

Chomczynski P and Sacchi N (1987). Single-step method of RNA isolation by acid guanidinium thiocyanate-phenolchloroform extraction. Anal. Biochem. 162: 156-159. http://dx.doi.org/10.1016/0003-2697(87)90021-2

Elgueta R, Benson MJ, de Vries VC, Wasiuk A, et al. (2009). Molecular mechanism and function of CD40/CD40L engagement in the immune system. Immunol. Rev. 229: 152-172.http://dx.doi.org/10.1111/j.1600-065X.2009.00782.x

Field J, Shahijanian F, Schibeci S, Johnson L, et al.; Australia and New Zealand MS Genetics Consortium (ANZgene) (2015). The MS risk allele of CD40 is associated with reduced cell-membrane bound expression in antigen presenting cells: implications for gene function. PLoS One 10: e0127080. http://dx.doi.org/10.1371/journal.pone.0127080

García-Bermúdez M, González-Juanatey C, López-Mejías R, Teruel M, et al. (2012). Study of association of CD40CD154 gene polymorphisms with disease susceptibility and cardiovascular risk in Spanish rheumatoid arthritis patients. PLoS One 7: e49214. http://dx.doi.org/10.1371/journal.pone.0049214

Jacobson EM, Concepcion E, Oashi T and Tomer Y (2005). A Graves' disease-associated Kozak sequence singlenucleotide polymorphism enhances the efficiency of $C D 40$ gene translation: a case for translational pathophysiology. Endocrinology 146: 2684-2691. http://dx.doi.org/10.1210/en.2004-1617

Kim TY, Park YJ, Hwang JK, Song JY, et al. (2003). A C/T polymorphism in the 5'-untranslated region of the CD40 gene is associated with Graves' disease in Koreans. Thyroid 13: 919-925. http://dx.doi.org/10.1089/105072503322511319

Lee HY, Jeon HS, Song EK, Han MK, et al. (2006). CD40 ligation of rheumatoid synovial fibroblasts regulates RANKLmediated osteoclastogenesis: evidence of NF-kappaB-dependent, CD40-mediated bone destruction in rheumatoid arthritis. Arthritis Rheum. 54: 1747-1758. http://dx.doi.org/10.1002/art.21873

Lee YH, Bae SC, Choi SJ, Ji JD, et al. (2015). Associations between the functional CD40 rs4810485 G/T polymorphism

Genetics and Molecular Research 15 (4): gmr15048775 
and susceptibility to rheumatoid arthritis and systemic lupus erythematosus: a meta-analysis. Lupus 24: 1177-1183. http://dx.doi.org/10.1177/0961203315583543

Li M, Sun H, Liu S, Yu J, et al. (2012). CD40 C/T-1 polymorphism plays different roles in Graves' disease and Hashimoto's thyroiditis: a meta-analysis. Endocr. J. 59: 1041-1050. http://dx.doi.org/10.1507/endocrj.EJ12-0126

Liu MF, Chao SC, Wang CR and Lei HY (2001). Expression of CD40 and CD40 ligand among cell populations within rheumatoid synovial compartment. Autoimmunity 34: 107-113. http://dx.doi.org/10.3109/08916930109001958

Liu R, Xu N, Wang X, Shen L, et al. (2012). Influence of MIF, CD40, and CD226 polymorphisms on risk of rheumatoid arthritis. Mol. Biol. Rep. 39: 6915-6922. http://dx.doi.org/10.1007/s11033-012-1518-y

Livak KJ and Schmittgen TD (2001). Analysis of relative gene expression data using real-time quantitative PCR and the $\left.\left.2^{(-\Delta \Delta \mathrm{C}(\mathrm{T})}\right)\right)$ Method. Methods 25: 402-408. http://dx.doi.org/10.1006/meth.2001.1262

Martínez-Cortés G, Salazar-Flores J, Fernández-Rodríguez LG, Rubi-Castellanos R, et al. (2012). Admixture and population structure in Mexican-Mestizos based on paternal lineages. J. Hum. Genet. 57: 568-574. http://dx.doi. org/10.1038/jhg.2012.67

McInnes IB and Schett G (2011). The pathogenesis of rheumatoid arthritis. N. Engl. J. Med. 365: 2205-2219. http://dx.doi. org/10.1056/NEJMra1004965

Miller SA, Dykes DD and Polesky HF (1988). A simple salting out procedure for extracting DNA from human nucleated cells. Nucleic Acids Res. 16: 1215. http://dx.doi.org/10.1093/nar/16.3.1215

Orozco G, Eyre S, Hinks A, Ke X, et al.; Wellcome Trust Case Control consortium YEAR Consortium (2010). Association of CD40 with rheumatoid arthritis confirmed in a large UK case-control study. Ann. Rheum. Dis. 69: 813-816. http:// dx.doi.org/10.1136/ard.2009.109579

Perricone C, Ceccarelli F and Valesini G (2011). An overview on the genetic of rheumatoid arthritis: a never-ending story. Autoimmun. Rev. 10: 599-608. http://dx.doi.org/10.1016/j.autrev.2011.04.021

Peters AL, Stunz LL and Bishop GA (2009). CD40 and autoimmunity: the dark side of a great activator. Semin. Immunol. 21: 293-300. http://dx.doi.org/10.1016/j.smim.2009.05.012

Raychaudhuri S, Remmers EF, Lee AT, Hackett R, et al. (2008). Common variants at CD40 and other loci confer risk of rheumatoid arthritis. Nat. Genet. 40: 1216-1223. http://dx.doi.org/10.1038/ng.233

Reparon-Schuijt CC, van Esch WJ, van Kooten C, Schellekens GA, et al. (2001). Secretion of anti-citrullinecontaining peptide antibody by B lymphocytes in rheumatoid arthritis. Arthritis Rheum. 44: 41-47. http://dx.doi. org/10.1002/1529-0131(200101)44:1<41::AID-ANR6>3.0.CO;2-0

Schmittgen TD and Livak KJ (2008). Analyzing real-time PCR data by the comparative C(T) method. Nat. Protoc. 3: 1101-1108. http://dx.doi.org/10.1038/nprot.2008.73

Shuang C, Dalin L, Weiguang Y, Zhenkun F, et al. (2011). Association of CD40 gene polymorphisms with sporadic breast cancer in Chinese Han women of Northeast China. PLoS One 6: e23762. http://dx.doi.org/10.1371/journal. pone. 0023762

Sokolova EA, Malkova NA, Korobko DS, Rozhdestvenskii AS, et al. (2013). Association of SNPs of CD40 gene with multiple sclerosis in Russians. PLoS One 8: e61032. http://dx.doi.org/10.1371/journal.pone.0061032

Suzuki A, Kochi Y, Okada Y and Yamamoto K (2011). Insight from genome-wide association studies in rheumatoid arthritis and multiple sclerosis. FEBS Lett. 585: 3627-3632. http://dx.doi.org/10.1016/j.febslet.2011.05.025

Tomer Y, Concepcion E and Greenberg DA (2002). A C/T single-nucleotide polymorphism in the region of the CD40 gene is associated with Graves' disease. Thyroid 12: 1129-1135. http://dx.doi.org/10.1089/105072502321085234

Vazgiourakis VM, Zervou MI, Choulaki C, Bertsias G, et al. (2011). A common SNP in the CD40 region is associated with systemic lupus erythematosus and correlates with altered $C D 40$ expression: implications for the pathogenesis. Ann. Rheum. Dis. 70: 2184-2190. http://dx.doi.org/10.1136/ard.2010.146530

Wagner M, Sobczyński M, Bilińska M, Pokryszko-Dragan A, et al. (2015). MS risk allele rs1883832T is associated with decreased mRNA expression of CD40. J. Mol. Neurosci. 56: 540-545. http://dx.doi.org/10.1007/s12031-015-0490-0

Wellcome Trust Case Control Consortium (2007). Genome-wide association study of 14,000 cases of seven common diseases and 3,000 shared controls. Nature 447: 661-678. http://dx.doi.org/10.1038/nature05911

Yi CQ, Ma CH, Xie ZP, Cao Y, et al. (2013). Comparative genome-wide gene expression analysis of rheumatoid arthritis and osteoarthritis. Genet. Mol. Res. 12: 3136-3145. http://dx.doi.org/10.4238/2013.March.11.3 